\title{
Measurement of the respiratory electron transport system (ETS) activity in marine sediments: state-of-the-art and interpretation. II. Significance of ETS activity data
}

\author{
J. C. Relexans* \\ Laboratoire d'Océanographie Biologique, CNRS-URA 197, Université Bordeaux 1, Avenue des Facultés, \\ F-33405 Talence CEDEX, France
}

\begin{abstract}
The activity of the respiratory electron transport system (ETSA), measured in vitro in conditions of $V_{\max }$ (i.e. with saturation of electron donors and acceptors), represents the respiratory potential of all communities sampled. From analysis of surface sediments from various oceanic areas, ETSA has been found to be correlated with the biopolymer (protein, carbohydrate, lipid) content which may represent the most labile fraction of the sedimentary organic matter. ETSA results expressed at constant temperature (e.g. $20^{\circ} \mathrm{C}$ ) can be considered as an estimator of biomass, especially of the microbia] biomass which contributes, in most cases, the greatest part of the sediment respiratory potential. Original and literature data reveal discrepancies between laboratory and field experiments, so that results obtained with cultured species cannot be directly applied to natural environments. A compromise conversion factor [particulate organic carbon (POC) biomass $(\mu \mathrm{g})=\operatorname{ETS}\left(\mu \mathrm{O}_{2} \mathrm{~h}^{-1}\right) \times 14.3$ ] is proposed by the author. At in situ temperature, ETSA may theoretically be converted to respiration $(R)$, which is the actual rate of electron transfer. The R/ETSA ratio used for conversion depends strongly on the availability of food. This ratio decreases from coastal to deep areas but results show that the gradient (from 0.4 in shallow sediments to 0.05 in deep sea areas, on average) is not as steep as previously thought. Due to the lack of accuracy of the R/ETSA ratio, the use of ETSA to calculate sediment community oxygen consumption is not very promising and direct measurements of respiration are preferable. Finally, it is concluded that the most important application of the ETSA measurement in sediments is its use as an estimator of the total microbial biomass.
\end{abstract}

KEY WORDS: ETS activity in sediments

\section{INTRODUCTION}

The organic supply at the sediment-water interface is an important step of the global carbon cycle because sedimentary organic compounds may either be mineralized by benthic metabolism (leading to the release of constitutive elements in the dissolved form) or buried as refractory (not available to the benthos) organic matter. The burial flux of refractory organic matter is the main sink for organic carbon in the ocean since preservation may last over geological time scales. The

•E-mail: relexans@biocean.u-bordeaux.fr fate of organic matter reaching the sediment-water interface depends on its amount and composition as well as on the 'environmental conditions' (e.g. temperature and pressure, nature and availability of the oxidants, sediment type, bioturbation) governing the benthos diversity and metabolic activities. As most oxidation of organic material occurs in organisms having respiratory chains, an overall estimate of catabolism has been proposed by measuring the respiratory electron transport system activity (ETSA). The method has been applied to marine studies by Packard (1969, 1971) and Packard et al. (1971). It consists of adding to homogenated samples a surplus of electron donors 
(NADH, NADPH, succinate) and of an artificial electron acceptor (INT: 2-p-iodophenyl-3-p-nitrophenyl-5phenyl tetrazolium chloride). The reduction of the colorless INT to red formazan can be followed using a spectrophotometer at $490 \mathrm{~nm}$. As the assay is made in vitro in conditions of $\mathrm{V}_{\max }$, it gives an estimate of the respiratory potential of the organisms or communities sampled, and exceeds, by far, the actual rate of electron transfer under natural conditions (Houri-Davignon et al. 1989).

The measure of ETSA is a highly sensitive method. It has been performed to calculate oxygen consumption rates in zones where in situ methods are too difficult and/or too expensive to carry out (e.g. the deep ocean), using the assumption of a constant conversion factor $R / E T S A$, where $R$ is respiration. The method received much attention for the water column by Packard (1985a, b) but its application to sediment studies brought not only specific technical problems (Relexans 1996) but also problems of interpretation of the results. In most cases, sediment contains a mixture of aerobic and anaerobic microbial populations and oxygen consumption is the combined result of different biological and chemical processes. Therefore, most authors have not been able to draw useful conclusions from ETSA measurements in sediments (Olanczuk-Neyman \& Vosjan 1977, de Wilde et al, 1984, 1986, Andersen \& Helder 1987) or else have had to elaborate calculations, with the help of oxygen-distribution models, to link ETSA to oxygen consumption (Christensen 1983). In recent years, the method has been somewhat neglected by researchers working on sediments. More than half of the relevant literature cited is between 1980 and 1987, with a maximum of papers in 1983.

The present paper is the second part of a status report on ETSA measurements in marine sediments (Relexans 1996). It focuses on relationships of ETSA to other biochemical and biological parameters, especially microbenthic biomass and respiration, in order to evaluate the significance and usefulness of the method for application to present oceanographic studies.

\section{ETSA VERSUS QUALITY OF SEDIMENTARY ORGANIC MATTER}

\section{Definition of labile organic matter}

Although sediment carbon and benthic biomass decrease from shelf regions towards the deep sea, total organic matter content does not correlate very closely with organism abundances nor with particulate organic carbon (POC) flux (Rowe et al. 1991). Similarly, ETSA/POC ratios calculated from literature data are highly variable according to geographic areas and water depth: they range from 155 (North Sea) to about $800 \mu \mathrm{O} \mathrm{O}_{2} \mathrm{~h}^{-1} \mathrm{~g}^{-1}$ of POC (Bay of Biscay in NE Atlantic) for intertidal areas, from 6 (North Sea) to about $450 \mu \mathrm{l}$ $\mathrm{O}_{2} \mathrm{~h}^{-1} \mathrm{~g}^{-1}$ (northeast and tropical Atlantic) on the continental shelf, and tend toward a uniform value of ca $43 \mu \mathrm{O}_{2} \mathrm{~h}^{-1} \mathrm{~g}^{-1}$ in deep sediments (Relexans 1996). This is probably due to variabilities in the 'quality' of organic matter in the sediment ('quality' meaning its availability to the benthos). Most of the organic matter reaching the sediment is decomposable (Berner 1980) but decomposes more or less rapidly, according to its age and origin (e.g. planktonic, terrestrial) and to environmental conditions at the sediment-water interface; only a small part (refractory matter) becomes buried in the sediment for very long periods. The labile part is a mixture of several categories of molecules (multi-G modeli Berner 1980), each of them being characterized by its ability to be used as substrate for benthic metabolism. Therefore, the usual term, 'ldbile matter', is somewhat difficult to define accurately, as its sense depends on, amongst other things, the time scale considered.

Chemical methods can be used to assess the 'labile' fraction of organic matter. Usually, this fraction is considered to consist either of the part hydrolysable by weak acids, or of the macromolecular content which can be easily extracted (for references see Relexans et al. 1993b). Possible methodologically induced discrepancies have to be taken into account in comparative studies on the relationships between ETSA and the quality of organic matter.

\section{Data}

In the present study, the labile fraction was taken as the sum $(\Sigma)$ of proteins [extracted by $0.1 \mathrm{~N} \mathrm{NaOH}$ for $2 \mathrm{~h}$ at $60^{\circ} \mathrm{C}$ and dosed using Bradford's (1976) method], carbohydrates [extracted with boiling water, $10 \mathrm{~min}$ at $100^{\circ} \mathrm{C}$ and dosed using Dubois et al.'s (1956) method] and lipids [ponderal method after extraction according to Bligh \& Dyer (1959)]. These studies were carried out on surface $(0$ to $1 \mathrm{~cm}$ ) layers from different areas of the northeast and tropical Atlantic, ranging from carbonrich sediments of coastal zones (Relexans et al. 1992) to very carbon-poor sediments from deep, oligotrophic, zones (Relexans et al. 1993a). The results are shown in Fig. 1A (ETSA vs $\Sigma$ of proteins, carbohydrates, lipids) and $1 B$ (ETSA vs proteins).

The orthogonal regression lines between ETSA and the macromolecular (biopolymer) content of the sedimentary organic matter for the coastal areas studied (mouth of the Gironde estuary, Bassin d'Arcachon, continental shelf of the Bay of Biscay, France) are as follows: 


$$
\begin{gathered}
\text { ETSA }=-2.9+101.7( \pm 9.8 ; 95 \% \mathrm{Cl}) \times \Sigma \\
\mathrm{r}^{2}=0.78 ; \mathrm{n}=92 \\
\text { ETSA }=-5.5+273( \pm 14 ; 95 \% \mathrm{CI}) \times \text { protein } \\
\mathrm{r}^{2}=0.75 ; \mathrm{n}=93
\end{gathered}
$$

with ETSA in $\mu \mathrm{O} \mathrm{O}_{2} \mathrm{~h}^{-1}$ (at $20^{\circ} \mathrm{C}$ ) and $\Sigma$ and protein in $\mathrm{mg}$; $\mathrm{Cl}$ is confidence interval. The $y$-axis intercepts do not differ significantly from zero.

\section{Discussion}

In spite of the good correlation coefficients calculated for all the values together, ECOFER (samples from the continental slope and rise of the Bay of Biscay) and EUMELI (meso- and oligotrophic sites of the northeast tropical Atlantic; Relexans et al. 1996) results form a group of values separate from the others (Fig. 1): in these sediments, the macromolecular content measured is greater than expected from the equations above. By comparing the macromolecular content measured in the surface $(0$ to $1 \mathrm{~cm})$ and in deeper layers $(10 \mathrm{~cm}$, i.e. at depths where the sedimentary organic matter reaches low constant values and is, therefore, thought to be mainly refractory), it may be concluded that, in these carbon-poor sediment areas, only a small proportion (about $30 \%$ ) of the measured macromolecular content really corresponds to labile organic matter (Relexans et al. 1992, 1993a, Elfacir 1993); the rest is probably contributed by 'humic-like substances' (geopolymers) or other refractory molecules, which interfere with colorimetric and/or fluorimetric methods. This interference is likely to be extremely important for carbon-poor sediments, but might well be negligible in coastal sediments which contain large amounts of true biopolymers.

A provisional conclusion can be drawn from these results: in contrast to the variations of ETSA/POC ratios, ETSA/macromolecular content ratios are likely to be more constant, although their absolute values must be considered prudently. At least in coastal ecosystems, it will be important to compare these ETSA/ $\Sigma$ and ETSA/protein ratios with those in living material, to assess the respective proportions of biomass and of detrital macromolecules in the (chemically) 'labile' organic matter content measured with the methods above.

\section{ETSA VERSUS BIOMASS}

The study of the relationship between ETSA and biomass is not easy because it has to involve laboratory experiments along with field studies. Within these 2 methods of investigation, selection of biomass parame-
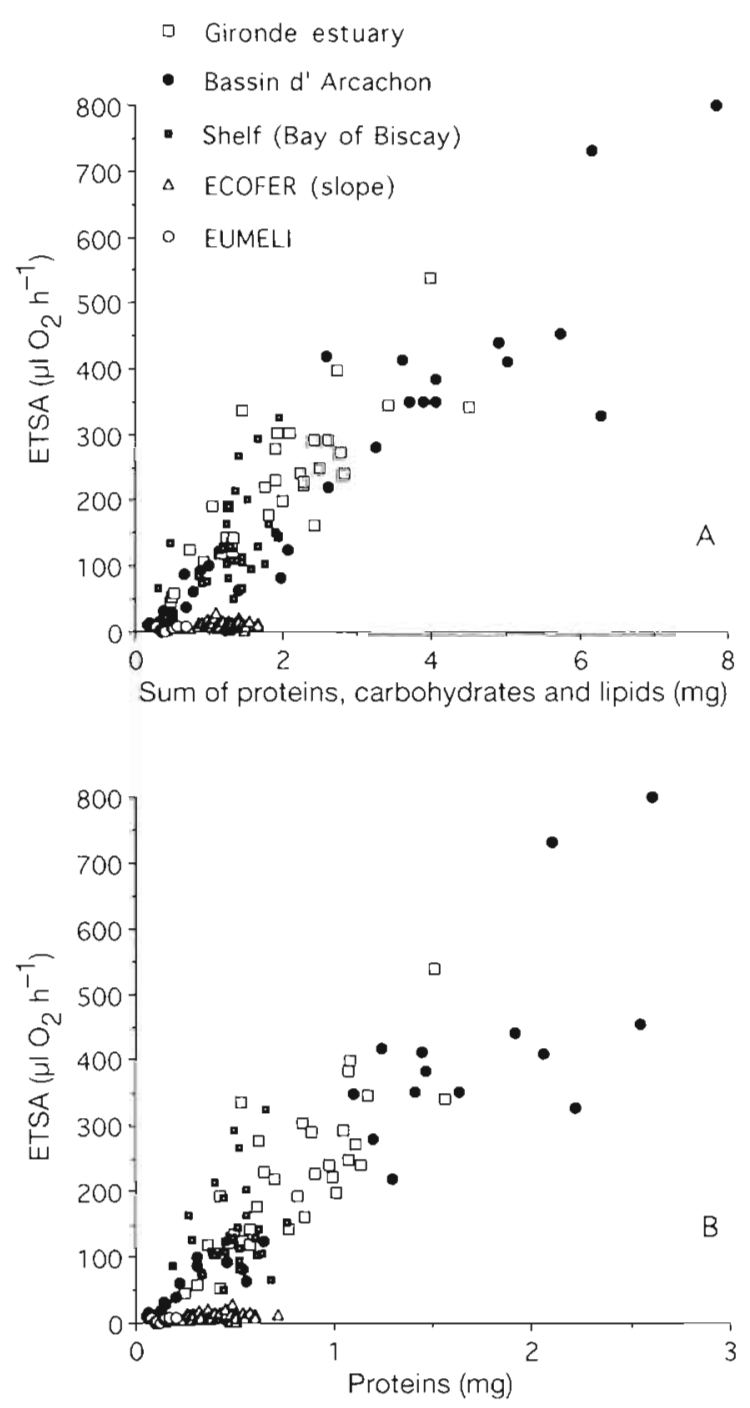

Fig. 1. ETSA vs (A) the sum $\left(\sum\right)$ of proteins, carbohydrates and lipids, and (B) proteins. ETSA is in $\mu \mathrm{lO} \mathrm{O}_{2} \mathrm{~h}^{-1} \mathrm{~g}^{-1}$ (dry weight) at $20^{\circ} \mathrm{C}$

ters will not necessarily be the same; moreover, as conditions will differ (especially concerning food supply), results obtained with laboratory experiments will not be directly applicable to natural environments.

Relationships between ETSA and biomass parameters have been extensively studied with phytoplankton (e.g. ETSA/chlorophyll a ratios; see Romano et al. $1987 \mathrm{~b}$ ) but very few data are available for benthic organisms. Data presented in this section deal largely with bacteria; they involve results of laboratory and field experiments on various species of bacteria, none of them characteristic of benthic habitats. However, there is no reason to suspect important differences in biomass characteristics amongst free pelagic bacteria attached pelagic bacteria and benthic bacteria ( $P$. Caumette pers. comm.). For these organisms, the most 
Table 1 ETSA and biomass parameters from laboratory experiments. For bacteria, results are for $10^{7}$ cells. POC, protein: $\mu$ g; ATP: ng; ETSA: $\mu \mathrm{I} \mathrm{O}_{2} \mathrm{~h}^{-1}$ at $20^{\circ} \mathrm{C}$, converted when necessary to Kenner \& Ahmed's (1975) norm; ETS/POC: $\mu \mathrm{l} \mathrm{O} \mathrm{h}^{-1} \mathrm{mg}^{-1} \mathrm{POC}$

\begin{tabular}{|c|c|c|c|c|c|c|}
\hline & $\begin{array}{c}\mathrm{POC} \\
(\mu g)\end{array}$ & $\begin{array}{c}\text { Protein } \\
(\mu g)\end{array}$ & $\begin{array}{l}\text { ATP } \\
(\mathrm{ng})\end{array}$ & $\begin{array}{c}\text { ETSA } \\
\left(\mu \mathrm{O}_{2} \mathrm{~h}^{-1}\right)\end{array}$ & $\begin{array}{l}\text { ETSA/POC } \\
\quad\left(\mu \mathrm{O} \mathrm{O}_{2}\right. \\
\left.\mathrm{h}^{-1} \mathrm{mg}^{-1}\right)\end{array}$ & Source \\
\hline \multicolumn{7}{|l|}{ Bacteria } \\
\hline \multicolumn{7}{|l|}{ Freshwater bacteria } \\
\hline Serratia rubidea & 5.5 & 6.6 & & 0.58 & 105 & Relexans et al. (1984) \\
\hline Pseudomonas fluorescens & 2.45 & 3.2 & & 0.55 & 225 & \\
\hline Bacillus subtilis & 1.74 & 1.66 & & 0.41 & 236 & Brugeaille (1988) \\
\hline Sarcina lutea & 2.98 & 0.34 & & 0.13 & 44 & \\
\hline Staphylococcus saprophyticus & 0.71 & 0.25 & & 0.03 & 48 & \\
\hline \multicolumn{7}{|l|}{ Marine bacteria } \\
\hline Pseudomonas denitrificans & & & & 0.39 & & Christensen \& Packard (1979) \\
\hline Pseudomonas perfectomarinus & & & & $0.04-0.9$ & & \\
\hline (peptone) & & 1.89 & & 0.65 & $340^{\circ}$ & Christensen et al. (1980) \\
\hline \multirow[t]{2}{*}{ (glucose) } & & 1.89 & & 0.37 & $196^{\mathrm{a}}$ & \\
\hline & & & & 3.15 & & Packard et al. (1983) \\
\hline Serratia marinorubra & & & & $\begin{array}{l}0.03 \\
0.39\end{array}$ & & Christensen \& Packard (1979) \\
\hline Serratia plymutica & 1.27 & & & 0.85 & 669 & Brugeaille (1988) \\
\hline Vibrio adaptatus & & & & $\begin{array}{l}0.9 \\
0.11\end{array}$ & & $\begin{array}{l}\text { Christensen \& Packard (1979) } \\
\text { Christensen et al. (1980) }\end{array}$ \\
\hline Vibrio alginolyticus & 2.3 & & & 1.31 & 570 & Brugeaille (1988) \\
\hline Vibrio anguillarum & & & & 0.6 & & Christensen \& Packard (1979) \\
\hline (peptone) & 2.65 & & & 0.34 & 128 & Christensen et al. (1980) \\
\hline (glucose) & & & & 0.26 & 98 & \\
\hline Vibriosp. & & & & 0.39 & & \\
\hline \multicolumn{7}{|l|}{ Natural mixture } \\
\hline (control) & & & 0.58 & 0.043 & $294^{6}$ & Romano et al. (1987a) \\
\hline$\left(+\mathrm{NH}_{4}\right)$ & & & 0.97 & 0.059 & $242^{b}$ & \\
\hline$(+\mathrm{AAC})$ & & & 2.73 & 0.594 & $868^{b}$ & \\
\hline Mean & 2.4 & & & 0.5 & 290 & \\
\hline \multicolumn{7}{|l|}{ Meiofauna } \\
\hline Nematodes (mixed populations) & & & & & $55^{\mathrm{d}}$ & Relexans (1989) \\
\hline Copepods (mixed populations) & & & & & $86^{\mathrm{d}}$ & \\
\hline \multicolumn{7}{|l|}{ Macrofauna } \\
\hline Corophium volutator & & & & & $31^{\mathrm{a}}$ & Cammen et al. (1990) \\
\hline Nereis virens & & & & & $18.5^{\mathrm{a}}$ & \\
\hline
\end{tabular}

important factors acting on biomass [e.g. number of individuals, POC, adenosine triphosphate (ATP) contents] are, by far, the nutritional conditions and the effects of predation, whatever the nature (planktonic or benthic) of their way of life.

\section{Laboratory experiments}

Results

Results (Table 1) may be summarized as follows:

(1) With bacteria, all parameters, expressed per $10^{7}$ cells, displayed very large variations between different species: 1 to 8 times for POC, 1 to 26 for protein, 1 to 38 for ETSA. Moreover, within a single species or population, variations occurred according to the nutritional. conditions in the experiments: 1 to 5 times for ATP, 1 to 22 for ETSA (Pseudomonas perfectomarinus; Christensen \& Packard 1979).

(2) ETSA/POC ratios ( $\mu \mathrm{l} \mathrm{O} \mathrm{O}_{2} \mathrm{~h}^{-1} \mathrm{mg}^{-1}$ POC) in bacteria varied from 44 to 868 (i.e. ca 20 -fold); ETSA/POC averaged $290 \pm 142(95 \% \mathrm{CI} ; \mathrm{n}=14)$.

(3) ETSA/POC ratios in bacteria were about 3 to 5 time those in meiofauna and 10 to 16 times those in the macrofauna.

\section{Discussion}

Single- or mixed-species cultures under controlled conditions allow large amounts of biomass to be obtained with practically no detritus. Therefore, biomass parameters (POC, cell numbers, protein and ATP) are 
easy to evaluate; differing laboratory conditions, especially food supply, however, may lead to differing cell sizes and/or organic composition, and, subsequently, to differing ratios between these biomass parameters. In Table 1, POC content for $10^{7}$ cells varied from 1.3 to $2.65 \mu \mathrm{g}$ POC (mean: 2) in marine bacteria and from 0.7 to $5.5 \mu \mathrm{g}$ POC (mean: 2.7) for freshwater bacteria. These values are greater than those usually given in the literature-0.1 (Bianchi 1989, Rowe et al. 1991); 0.2 (Meyer-Reil et al. 1980); 0.2 to 1 (oligotrophic and eutrophic waters, respectively; Sorokin 1978); 1.15 (Mare 1942) $\mu \mathrm{g}$ POC $10^{-7}$ cells - but remain in the range 0.01 to $6 \mu \mathrm{g}$ POC $10^{-7}$ cells cited by Van Es \& Meyer-Reil (1982). Therefore, bacterial number is of little help in evaluating biomass, and POC remains the reference parameter, both in cultures and in natural environments. As for ATP, although little information is given in Table 1 , this nucleotide is often considered a good biomass reference (Hamilton \& Holm-Hansen 1967), in spite of the possible variations in ATP content per biomass unit, discussed by Karl (1980). For micro-organisms, a POC/ATP ratio of 250 (Holm-Hansen 1969) is commonly accepted by the oceanographic community, while for metazoa, the limited data compiled by Karl (1980) for POC/ATP indicated lowervalues (ca 100: w/w).

Table 1 shows ETSA/POC to have been ca $0.3 \mu \mathrm{l} \mathrm{O}$

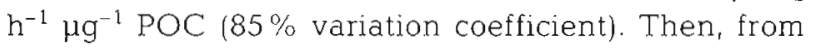
the assumption that $\mathrm{POC}=250$ times ATP, ETSA/ATP was calculated as $75 \mu \mathrm{O}_{2} \mathrm{~h}^{-1} \mu^{-1}$ ATP. The variations in ETSA per unit biomass, reported for monospecific populations cultivated on different nutritive media, can be related to the nutritive conditions: Christensen et al. (1980) found ETSA/POC ratios from 98 (with glucose) to $128 \mu \mathrm{l} \mathrm{O}_{2} \mathrm{~h}^{-1} \mathrm{mg}^{-1} \mathrm{C}$ (with peptone) for Vibrio anguillarum, and from 196 (with glucose) to $340 \mu \mathrm{O} \mathrm{O}_{2}$ $\mathrm{h}^{-1} \mathrm{mg}^{-1} \mathrm{C}$ (with peptone) for Pseudomonas perfectomarinus. In the same way, Romano et al. (1987a) found ETSA/ATP ratios 3 times greater in populations supplemented with amino acids than in those not supplemented or else supplemented with $\mathrm{NH}_{4}$; this cannot be explained by cell size variations alone, as high respiration rates were also noted in the presence of amino acids. Synthesis of ETS units would represent a possible adaptation by micro-organisms to supplementation with highly assimilable molecules. As food supply in cultures is likely to be much more advantageous to microbial populations than in natural environments, the values and variations of ETSA/POC biomass and ETSA/ATP ratios measured in laboratory experiments might have little relevance to equivalent values measured in natural waters or sediments, where populations are thought to be 'adapted' to average steadystate environmental conditions.

Concerning ETSA/POC in meiofauna and macrofauna, the limited data (see Table 1) clearly show lower respiratory potential per unit of biomass for these taxa than for most of the bacteria. Assuming a mean POC/ATP ratio of ca 100 (Karl 1980), ETSA/ATP in meiofauna would be from ca 6 (nematodes) to ca 9

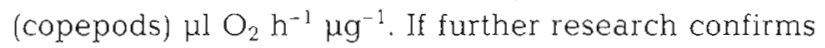
these preliminary results, ETSA will not be a satisfactory index of biomass for a whole benthic community. Therefore, the relative contribution by different components to the measured benthic respiratory potential is an important question, which is discussed later.

\section{Field data}

Field studies do not run the risk of the artefacts previously discussed in relation to laboratory conditions. But they suffer from other drawbacks: in natural ecosystems where biomass carbon is generally less than detritus carbon, the biomass cannot be evaluated using direct, simple chemical methods. The correct approach has to include complete analysis of all living benthic components (i.e. meio-, micro- and bacteriobenthos; macrofauna is generally not analysed in the small samples used for ETSA assays) with conversion of these counts to biomass carbon. This approach is too tedious, however, for routine application. For these reasons, ATP is more often preferred as an estimate of microbionass.

Results

ETSA and total micro- and meiobenthic biomass have rarely been analysed from the same samples. Data taken from the literature are shown in Table 2. For sediment samples, bacteria carbon biomass, calculated from biovolumes, are available only for Baltic Sea sediment. For water samples, a conversion factor was necessary to convert bacterial number to carbon; according to Sorokin (1978), a factor of $1 \mu \mathrm{g} \mathrm{C} 10^{-7}$ cells for Lake Geneva and $0.5 \mu \mathrm{g} \mathrm{C} 10^{-7}$ cells for the Mediterranean Sea and the Northern Indian Ocean was applied. For the Western Atlantic Ocean (Hobbie et al. 1972), bacterial numbers appeared to be abnormally low, compared with other biomass parameters such as ATP, and were not taken into account in carbon biomass estimates.

After normalization of the data in Table 2 by logarithmic transformation, ETSA is well correlated with bacterial POC (Fig. 2A) as well as with ATP (Fig. 2B). The equations of the orthogonal regression lines follow:

$\log \mathrm{ETSA}=-1.56+1.40( \pm 0.33 ; 95 \% \mathrm{CI}) \log$ bact. POC $r^{2}=0.75 ; n=21$ 
Table 2. ETSA and biomass parameters in natural environments. Same units as in Table 1. For the water column, ETSA is from heterotrophic organisms, i.e. total minus algal ETSA determined as chlorophyll a $\times$ conversion coefficient given by authors

\begin{tabular}{|c|c|c|c|c|c|c|c|}
\hline Water column & $\begin{array}{c}\text { Bact. } \\
\text { (no. } 1^{-1} \\
10^{-7} \text { cells) }\end{array}$ & $\begin{array}{c}\operatorname{ATP} \\
\left(\lg 1^{-1}\right)\end{array}$ & $\begin{array}{l}\text { ETSA } \\
\left(\mu \mathrm{l} \mathrm{O}_{2}\right. \\
\left.\mathrm{h}^{-1} \mathrm{1}^{-1}\right)\end{array}$ & n & $\begin{array}{c}\text { ETSA/bact. C } \\
\left(\mu \mathrm{l} \mathrm{O} \mathrm{h}^{-1}\right. \\
\left.\mathrm{mg}^{-1}\right)\end{array}$ & $\begin{array}{c}\text { ETSAVATP } \\
\left(\mu \mathrm{O}_{2} \mathrm{~h}^{-1}\right. \\
\left.\mu \mathrm{g}^{-1}\right)\end{array}$ & Source \\
\hline \multicolumn{8}{|l|}{ Leman Lake (France) } \\
\hline Surface & 72.6 & & 39 & 2 & 537 & & Brugeaille (1988) \\
\hline $50 \mathrm{~m}$ & 15.5 & & 3.5 & & 226 & & \\
\hline \multicolumn{8}{|l|}{ Pavin Lake (France) } \\
\hline Surface & & 0.76 & 15 & 5 & & 20 & Brugeaille (1988) \\
\hline$>56 \mathrm{~m}$ & & 0.5 & 29 & 4 & & 60 & \\
\hline \multicolumn{8}{|l|}{ Atlantic } \\
\hline \multicolumn{8}{|l|}{ Cape Hatteras } \\
\hline Surface & & 0.47 & 13 & 2 & & 28 & Hobbic et al. (1972) \\
\hline $40 \mathrm{~m}$ & $17 \times 10^{-4}$ & 0.063 & 0.34 & & 5.4 & & \\
\hline$>100 \mathrm{~m}$ & $2 \times 10^{-4}$ & 0.016 & 0.019 & 3 & 1.2 & & \\
\hline \multicolumn{8}{|l|}{ Sargasso Sea } \\
\hline Surface & $2 \times 10^{-4}$ & 0.073 & 0.53 & 2 & 7.3 & & \\
\hline $50 \mathrm{~m}$ & & 0.075 & 1 & & 13.3 & & \\
\hline$>100 \mathrm{~m}$ & $8.5 \times 10^{-4}$ & 0.012 & 0.026 & 4 & 2.2 & & \\
\hline \multicolumn{8}{|l|}{ Niedilentalledu Sed } \\
\hline \multicolumn{8}{|l|}{ Cortiou } \\
\hline $\mathrm{POC}<400 \mu \mathrm{gl}^{-1}$ & 37 & 0.31 & 1.06 & 11 & 57 & 3.42 & Romano et al. (1987) \\
\hline $\mathrm{POC}>400 \mu \mathrm{g} \mathrm{l}^{-1}$ & 175 & 1.13 & 65.04 & 23 & 743 & 58 & \\
\hline \multicolumn{8}{|l|}{ Euprod } \\
\hline $\mathrm{POC}<400 \mu \mathrm{g} \mathrm{J}^{-1}$ & 47 & 0.14 & 3.1 & 42 & 132 & 22.1 & \\
\hline$P O C>400 \mu \mathrm{g} \mathrm{l}^{-1}$ & 132 & 0.9 & 37.55 & 7 & 569 & 42 & \\
\hline \multicolumn{8}{|l|}{ Eurin } \\
\hline $\mathrm{POC}<400 \mu \mathrm{g} \mathrm{l}^{-1}$ & 155 & 0.3 & 11.65 & 6 & 150 & 39 & \\
\hline Coastal surface waters & 122 & 0.3 & 6.35 & 36 & 104 & 19.1 & Garabelıan \{1992\} \\
\hline \multicolumn{8}{|l|}{ Liguro-Prov. Front } \\
\hline Surface & 33 & & 0.27 & & 16 & & \\
\hline $100-1000 \mathrm{~m}$ & 17 & & 0.61 & 4 & 72 & & \\
\hline \multicolumn{8}{|l|}{ Algerian Current } \\
\hline Surface & 49 & 0.012 & 1.9 & 31 & 78 & 158 & \\
\hline $\mathrm{POC}>400 \mu \mathrm{g} \mathrm{l}^{-1}$ & 1778 & 17.38 & 340.55 & 6 & 383 & 19.6 & \\
\hline $100-500 \mathrm{~m}$ & 10 & 0.009 & 1.35 & 34 & 270 & 150 & \\
\hline \multicolumn{8}{|l|}{ Surface microlayer } \\
\hline $\mathrm{POC}<6 \mathrm{mg} \mathrm{l}^{-1}$ & 440 & 1.4 & 16.9 & 63 & 77 & 17.6 & \\
\hline $6<\mathrm{POC}<20 \mathrm{mg} \mathrm{l}^{-1}$ & 600 & 4.43 & 70.7 & 30 & 236 & 16.7 & \\
\hline $\mathrm{POC}>20 \mathrm{mg} \mathrm{l}^{-1}$ & 2400 & 15.45 & 215.5 & 16 & 180 & 13.9 & \\
\hline \multicolumn{7}{|l|}{ Indonesia; $0-75 \mathrm{~m}$} & Garabetıan (1992) \\
\hline West (Banda) & & 0.07 & $1.2-3$ & & & 25 & Vosjan \& Nieuwland (1987) \\
\hline East (Arafura) & & $0.03-0.3$ & $1.4-7.1$ & & & 25 & \\
\hline Sediment & $\begin{array}{c}\text { Bact. } \\
\text { (no. } \mathrm{g}^{-1} \\
\left.10^{-7} \text { cells }\right)\end{array}$ & $\begin{array}{c}\text { ATP } \\
\left(\mu g g^{-1}\right)\end{array}$ & $\begin{array}{c}\text { ETSA } \\
\left(\mu l O_{2}\right. \\
\left.g^{-1}\right)\end{array}$ & $\mathrm{n}$ & $\begin{array}{c}\text { ETSA/bact. C } \\
\left(\mu \mathrm{IO}_{2} \mathrm{~h}^{-1}\right. \\
\left.\mathrm{mg}^{-1}\right)\end{array}$ & $\begin{array}{c}\text { ETSA/ATP } \\
\left(\mu \mathrm{O} \mathrm{O}_{2} h^{-1}\right. \\
\left.\mu g^{-1}\right)\end{array}$ & Source \\
\hline \multicolumn{8}{|l|}{ Baltic Sea } \\
\hline Tidal beaches & 103 & 0.12 & 1.03 & 5 & 20.4 & 9.4 & $\begin{array}{l}\text { Pamatmat et al. (1981), } \\
\text { Meyer-Reil et al. (1980) }\end{array}$ \\
\hline $11 \mathrm{~m}$ & & 0.6 & 2.84 & & & 4.7 & \\
\hline $18 \mathrm{~m}$ & 400 & 0.89 & 2.3 & 18 & 70 & 3.2 & $\begin{array}{l}\text { Graf et aI. }\{1983\} \\
\text { Meyer-Reil (1983) }\end{array}$ \\
\hline $21 \mathrm{~m}$ & & 1.3 & 3 & 3 & & 2.4 & Graf \& Bengtson (1984) \\
\hline \multicolumn{8}{|l|}{ NE Pacifici Washington } \\
\hline Continental shelf & & 1.31 & 20.25 & 4 & & 20.25 & Christensen (1981) \\
\hline $1800 \mathrm{~m}$ & & 0.4 & 5.8 & & & 14.5 & \\
\hline Puget Sound; $1800 \mathrm{~m}$ & & 2.45 & 53 & 4 & 22.3 & & \\
\hline \multicolumn{8}{|l|}{ NE Tropical Atlantic } \\
\hline $4500 \mathrm{~m}$ (oligotrophic area) & $175^{\circ}$ & & $3.9^{\circ}$ & & 220 & & Relexans et al. (1996) \\
\hline $3100 \mathrm{~m}$ (mesotrophic area) & $645^{\circ}$ & & $9^{3}$ & & 139 & & \\
\hline
\end{tabular}



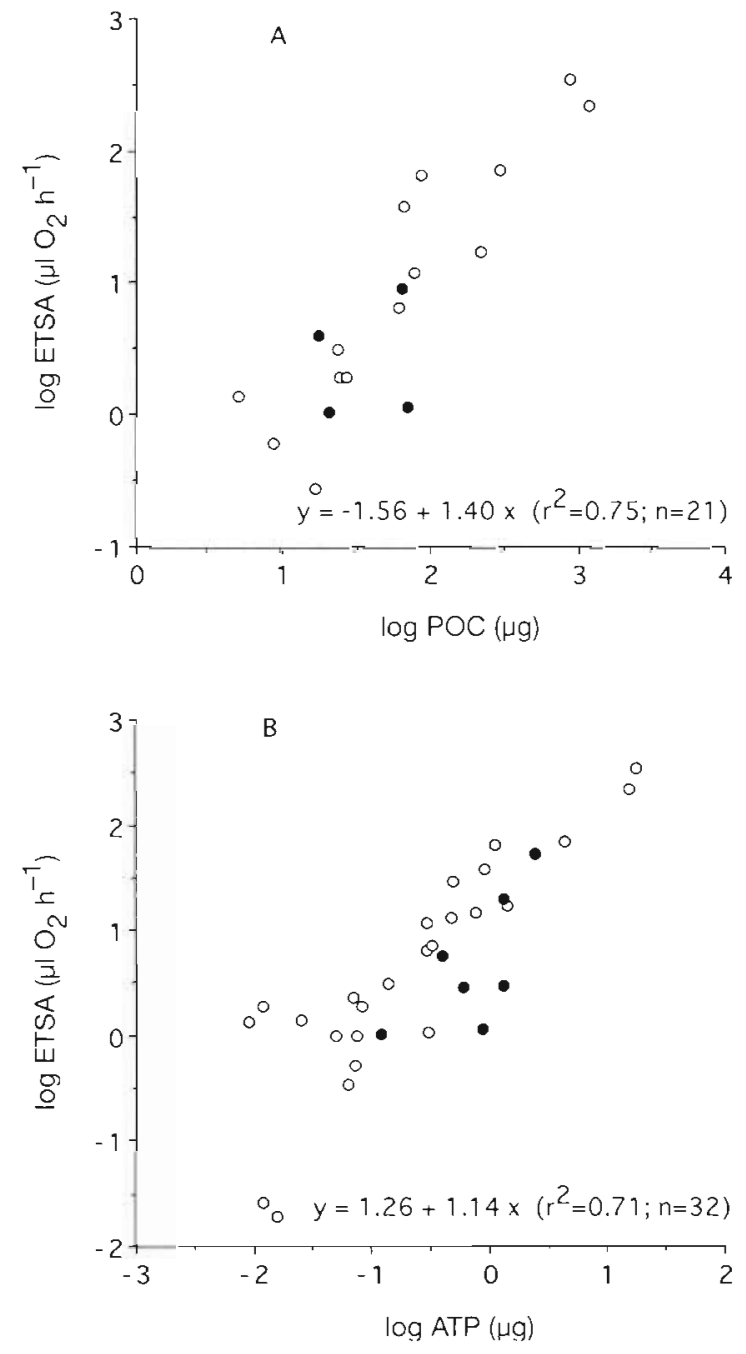

Fig. 2. ETSA vs (A) bacterial carbon and (B) ATP, after $\log$ transformation, from various environments. Open symbols: water column samples; dark symbols: sediment samples ETSA: $\mu \mathrm{O}_{2} \mathrm{~h}^{-1}$, at $20^{\circ} \mathrm{C}_{i}$ carbon and ATP: $\mu \mathrm{gg}$

and

$\log \mathrm{ETSA}=+1.26+1.14( \pm 0.19 ; 95 \%$ CI $) \log$ ATP

$$
\mathrm{r}^{2}=0.71 ; \mathrm{n}=32
$$

where ETSA is in $\mu \mathrm{O}_{2} \mathrm{~h}^{-1}$ at $20^{\circ} \mathrm{C}$; bacterial POC and ATP are in $\mu g$; and $C I$ is the confidence interval.

\section{Discussion}

Demonstration of the link between ETSA and calculated bacterial POC is important in that it shows the contribution of micro-organisms to measurements of overall respiratory potential. From the regression of ETSA versus POC (not represented), the mean

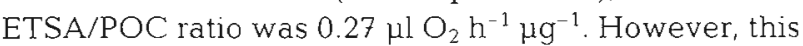

value is not very precise because (1) this ETSA is composite, including a contribution not only by the bacterial component, but also by the phytoplankton and the microzooplankton for surface waters as well as the phytobenthos (shallow areas), and the meio- and microbenthos for the sediments; and (2) uncertainties in estimating bacterial biomass from counts and use of conversion factors cannot be avoided.

Calculation of the algal contribution to total ETSA also requires a value for ETSA/chlorophyll a (chl a) in algae. Only a few values of this ratio, determined using cultures, are available in the literature (see Relexans et al. 1992). ETSA/chl $a$ in marine cultures varied from 4

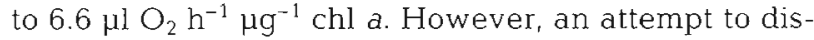
criminate ETSA of algae and of the heterotrophic components in intertidal sediments of the Bassin d'Arcachon, France (Relexans et al. 1992) showed that these conversion factors were too high, leading to estimates of algal ETSA sometimes greater than total ETSA. A new, lower ETSA/chl a value (1.89) was calculated from field results, allowing phytobenthic ETSA to be estimated from 37 to $80 \%$ of total ETSA (annual average) for sandy stations and from 9 to $14 \%$ for finegrained stations. To explain the discrepancy between cultures and field results, it was suggested either that phytobenthic populations at the studied stations were composed of species having low ETSA/chl a ratios, or that sediment contained significant amounts of detrital chl $a$, i.e. not linked to living electron transport structures. Therefore, in most cases, factors determined using cultures for converting chl a to algal ETSA cannot be applied directly in natural environments.

The meiobenthic contribution to biomass of heterotrophic benthos (macrofauna excluded) is estimated as 5 to $30 \%$ (Sorokin 1978, 1981) or less: 1 to $16 \%$ (Rowe et al. 1991). The only data on the ETSA of this component are from intertidal sediments in the Bassin d'Arcachon (Relexans et al. 1992) derived by applying the factors for converting biomass to ETSA for meiofauna, given in Table 1 . This study showed the contribution of meiobenthos to be generally less than $15 \%$ of heterotrophic ETSA, and less than $10 \%$ at most silty stations. Although these assessments of the different components of ETSA require refinement through further investigations, they nevertheless indicate the major importance of the microbial compartment in total ETSA (as in total biomass-POC), in most natural environments (except in near-surface waters and shallow, sandy sediments). The actual value of the mean ETSA/bacterial POC ratio remains rather imprecise, however.

The ETSA/ATP ratio from the regression of ETSA versus ATP (not represented) was $17.5 \mu \mathrm{O}_{2} \mathrm{~h}^{-1} \mu^{-1}$ ATP, lying between the mean value calculated for cultured bacteria $\left(75 \mu \mathrm{O}_{2} \mathrm{~h}^{-1}{\mu \mathrm{g}^{-1}}^{-1}\right.$ ) and that for meio- 
fauna (6 to $9 \mu \mathrm{lO}_{2} \mathrm{~h}^{-1} \mu \mathrm{g}{ }^{1}$ ). Owing to the low contribution by meiofauna and algae in most cases, the low ETSA/ATP ratio found in natural environments can be explained not by the influence of non-microbial components alone, but, more probably, by the different ETS equipment in cultured and natural bacterial populations. In most cases, bacterial populations appear to develop different amounts of ETS equipment to respond to the ambient food supply. Discrepancies between cultured and natural populations are now well documented: they may affect cell size and the ATP and ETS contents of individuals, as well as selecting populations able to adapt to the different conditions they encounter. They may affect not only bacterial populations but also algae (e.g. variations of $\mathrm{POC} / \mathrm{chl}$ a ratios according to light conditions and nutrient supply), and examples have been given of the errors that can be produced by carelessly applying results obtained with cultures to natural populations (Relexans et al. 1992). For these reasons, it may be considered that the ETSA/ATP ratio $=17.5$, calculated from the regression in Fig. 2B, is the most suitable one presently available for natural environments. If $\mathrm{POC}=$ $250 \mathrm{ATP}$, then ETSA/biomass-POC is estimated as 0.07

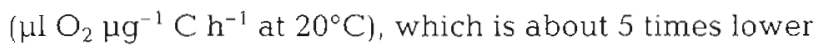
than the ratio $(0.3)$ found with bacterial cultures.

\section{Is ETSA an acceptable index for benthic biomass?}

This question can be divided into 3 parts:

(1) Are all living organisms equipped with electron transport systems?

(2) Is ETSA strictly linked to living material?

(3) Is the the amount of ETSA-producing equipment relatively constant in all cells in any environment?

The answers to these questions are as follows:

(1) The ETS is a membrane-linked mechanism for electron transport, existing in most living organisms, except for the obligate fermenting bacteria. This exception should not be of major importance in most marine systems. Therefore, each biomass unit of a respiring organism is expected to possess ETS equipment.

(2) The problem of persistence of ETSA after organisms are dead has been rarely studied: Bämstedt (1980) reported that freeze-killed individuals of the copepod Acartia tonsa, stored at $-20^{\circ} \mathrm{C}$, lost $50 \%$ of their ETSA within $30 \mathrm{~h}$ and that activity was completely lost after $74 \mathrm{~h}$. At $19^{\circ} \mathrm{C}$, in filtered and antibiotic-supplemented seawater, ETSA disappeared only within $3 \mathrm{~d}$. Although natural conditions are somewhat different from those applied in Bamstedt's (1980) experiments (e.g. presence of antibiotics), it is probable that remaining ETSA might persist for a few days after death, especially in cold waters. What proportion of ETSA measured in natural ecosystems might be attributed to detrital matter is unknown. The problem needs further studies but, henceforth, it seems that ETSA is unlikely to be as good an index as is ATP.

(3) Among parameters usually taken as biomass criteria (e.g. living POC, proteins, number of individuals, nucleotides), the most useful should be easily measurable in natural sediments as well as in cultures. ATP and ETSA meet this requirement, but biomass-POC, which is generally low compared to detrital POC, does not. Furthermore, the parameter values chosen as biomass indices should be relatively similar in all cells at any time. Numerous results have shown that this is not the case, since wide variations in the ratios of the above biomass criteria (ATP/POC and ETSA/POC) were observed according to environmental (especially nutritional) conditions. In spite of these difficulties, the highly significant relationship between ETSA and ATP in natural environments is remarkable. ETSA is probably not as good a biomass index as is ATP, but it seems easier to measure in sediments. When ETSA is considered, the best estimate of biomass from ETSA is the following:

$$
\begin{aligned}
& \text { biomass-POC }(\mu \mathrm{g})=\operatorname{ETSA}\left(\mu \mathrm{O} \mathrm{O} \mathrm{h}^{-1} \text { at } 20^{\circ} \mathrm{C}\right) / 0.070 \\
& =\mathrm{ETSA} \times 14.3
\end{aligned}
$$

The possible use of ETSA to estimate overall microbenthic biomass is an important application of the method since very few simple indices of this kind are available.

\section{ETSA VERSUS BENTHIC RESPIRATION}

The use of ETSA to calculate respiration rates has been broadly applied in plankton studies where respiration is not easy to measure directly (e.g. in the deep sea). The method is advantageous owing to its sensitivity and rapidity (Packard 1985b). However, such calculations need (1) conversion of the results obtained at the temperature of the assay to ETSA at the temperature in situ and (2) conversion of the potential electron transport (i.e. ETSA measurement) to electron transport rate under in situ conditions where, at least, electron donors are not in saturating concentrations. This conversion factor (R/ETSA) expresses the actual rate of functioning of the ETS equipment.

Correction for temperature is easy providing the activation energy is known (Packard et al. 1975). A crucial point is the value of the R/ETSA factor which has to be applied, since with experimental bacterial cultures, the ratio may vary from near 0 (starving conditions) to about 1 with high food supply (Christensen et al. 1980). Therefore, preliminary experi- 
ments should be carried out in any particular ecosystem to determine $R$ and ETSA and to determine the correct $R /$ ETSA ratio to apply (see Williams 1984). In spite of these difficulties, ETSA has been used to calculate oxygen consumption in deep-sea areas, applying low R/ETSA ratios (e.g. 0.0078; Christensen \& Packard 1977) corresponding to starvation conditions. However, very few experiments have been done to check the validity of this ratio (Christensen 1983).

The use of ETSA to calculate sediment-community oxygen consumption (SCOC) is much more difficult than for the water column, because (1) SCOC is expressed in terms of unit sediment area, i.e. its oxygen consumption is integrated over the entire sediment column. On the contrary, ETSA is measured in a volume from a particular sediment layer; generally, the depth in the sediment at which ETSA is zero is unknown and ETSA thus cannot be integrated. (2) In most sediments, the oxidation of organic matter does not take place only through oxic metabolism. Secondary oxidants can also serve as electron acceptors $\left(\mathrm{NO}_{3}{ }^{-}\right.$, metal ions, $\left.\mathrm{SO}_{4}{ }^{2-}, \mathrm{CO}_{3}{ }^{2-}\right)$ when the oxygen in the porewater is exhausted. While SCOC results only from aerobic processes (even if partly from the oxidization of anaerobic end products), ETSA in a particular layer of sediment may include significant components from both aerobic and anaerobic micro-organisms (Christensen \& Packard 1977), the relative importance of which would depend on the location of this layer in relation to the oxygen distribution. As anaerobic metabolism is thought to be initiated when oxygen concentration is depleted below $5 \%$ of saturation (Jørgensen 1983), ETSA in the oxic layer is probably due mainly to aerobic organisms.

\section{Determination of $R$ /ETSA ratios in sediments}

\section{Laboratory experiments}

A direct comparison between oxygen consumption and ETSA can be made only if anaerobic metabolism is absent. This is the case when the surficial layer is sampled and measured for both respiration and ETSA in laboratory experiments.

Such methodology was carried out on surficial sediments from the Bassin d'Arcachon (Brugeaille 1988, Relexans 1989). After sampling of the surficial film (1 to $2 \mathrm{~mm}$ ) with a plastic spoon, a few $\mathrm{cm}^{3}$ were placed in respiratory flasks in such a way that the sediment at the bottom of the flasks formed a layer too thin to support anoxic conditions. Then, oxygen consumption was measured in each flask equipped with a Clark's electrode, at controlled temperature. After the experiment, the sediment was removed onto a glass filter and analysed for ETSA.
Field experiments

In most natural sediments, oxygen is exhausted at depth $z_{\mathrm{e}}$ below the surface $z_{0}$ (Fig. 3A). The depth $z_{\mathrm{e}}$ can be very close (a few $\mathrm{mm}$ ) to the surface in coastal eutrophic zones (Fig. 3C). In contrast, oxygen is still present in deep layers of the sediments from oligotrophic zones and tends to a constant concentration at depth $z_{c}$ (Fig. 3B). In all cases, SCOC measured with a benthic chamber or calculated from oxygen profiles integrates oxygen consumption exclusively by all the oxygen-respiring organisms in the sediment column. To determine R/ETSA ratios, either SCOC should be compared with ETSA integrated over the aerobic zone, or, if ETSA is measured in a particular layer of sediment, SCOC in this single layer should be taken into account. For any layer below the surface (e.g. $z_{0}-z_{1}$ layer), oxygen consumption can be calculated from Fig. $3 \mathrm{~A}$ and $\mathrm{B}$ : as $\mathrm{SCOC}$ is represented by the total area delimited by the curve of oxygen distribution and a vertical line passing through the zero value (general case) or a constant value (oligotrophic zones) of oxygen concentration, i.e. area $a+c$, oxygen consumption due to the $z_{0}-z_{1}$ layer is only represented by area a:

$$
\operatorname{SCOC}_{\left(z_{0}-z_{1}\right)}=\text { total SCOC } \times a /(a+c)
$$

Conversely, in eutrophic coastal areas (Fig, 3C), ETSA measured in the $z_{0}-z_{1}$ layer may be corrected by $a /(a+b)$ to be applied to this single layer before comparison with SCOC.
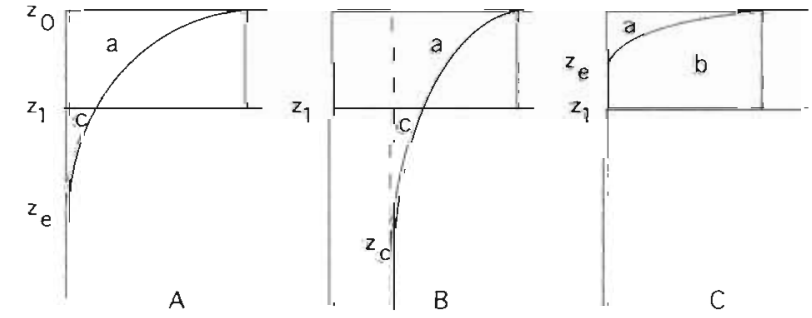

Fig. 3. Porewater oxygen profiles. (A) General case; (B) oligotrophic zones; (C) coastal rich sediment (see text)

\section{Results}

The methods described above have been applied to sediments from coastal to abyssal zones. The results, as well as a few data found in the literature, are presented in Table 3. Even excluding the values manifestly too high (see discussion below), R/ETSA ratios were very variable, from 0.0004 in abyssal northwest Atlantic (Christensen 1983) to 0.35 on the continental shelf (de Wilde et al, 1986). However, a trend of decreasing R/ETSA with increasing depth can be noted (Fig. 4). 







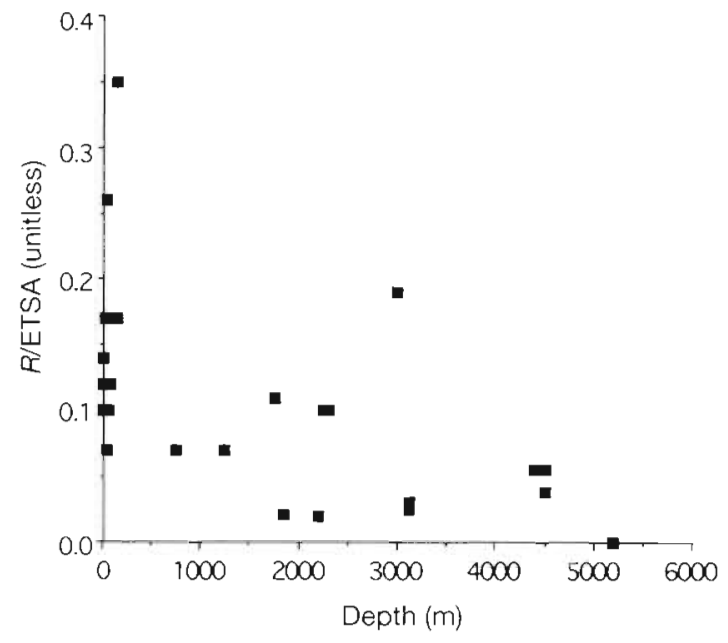

Fig. 4. Variations of $R / E T S A$ ratios according to depth

\section{Discussion}

The variations in $R / E T S A$ ratios may have 2 origins: (1) methodological bias which can be attributed to ETSA and/or SCOC measurements, and (2) physiological causes.

The most questionable SCOC results in Table 3 are those from on-board experiments. Actually, a comparison of in situ and on-board results, on a large scale, with literature data compiled from various marine areas (Etcheber et al. unpubl.), revealed no significant differences between the various methods. Therefore, I consider as reasonable the SCOC values used here for R/ETSA calculations in Table 3.

On the contrary, the highest ETSA values reported for each of the areas considered may be attributed to results obtained with Olanczuk-Neyman \& Vosjan's methodology (note the R/ETSA value of 1.5 for an intertidal sediment, which seems unrealistic). One can believe (Relexans 1996) that the extraction of the respiratory enzymes involved in ETSA must have been incomplete using the mechanical method, and that, consequently, ETSA was underestimated. Therefore, the results obtained with this methodology (noted as 'discarded' in Table 3) have been excluded for drawing the curve of $R /$ ETSA versus depth in Fig. 4.

Variations of R/ETSA with the physiological state of organisms is much more interesting to consider. Assuming that ETSA expresses the overall dehydrogenase activity at $V_{\text {max }}$ an $R / E T S A$ ratio of 0.5 should correspond to the $K_{m}$ concentration of available substrate for respiration. The ratio may vary from near zero in carbon starvation conditions to about 1 in cultures supplemented with organic substrate (Christensen et al. 1980). That R/ETSA ratios were found by Christensen (1983) to decrease from shallow to deep sea sediments led him to attribute to deep sea environments drastic starvation conditions. While a similar trend is evident in the present results, the decrease in R/ETSA values shown in Fig. 4 is not as steep as expected from Christensen's (1983) paper. I conclude that deep sea benthic communities are better adapted to their moderate food supply than might have been expected from previous studies.

This paragraph has shown that it is difficult to determine appropriate $R /$ ETSA values. Moreover, their use in calculating respiration from ETSA measurements (which was the initial goal) appears fraught with complications. Modern, direct methods, such as in situ benthic chambers, as well as the use of electrodes, seem the most appropriate and for measuring SCOC. How the $R / E T S A$ ratios vary with environmental conditions remains of fundamental importance to understanding the adaptative links between organisms and their habitats.

\section{CONCLUSION}

The application of ETSA measurements to sediments has been examined using original results and results from the literature data. The main conclusions of the paper follow.

(1) ETSA correlates well with the labile fraction of the sedimentary organic matter, defined as the biopolymer (protein, carbohydrate, lipid) content. Unfortunately, the ETSA/biopolymer ratio has been affected by methodological bias in the determination of the macromolecules.

(2) Correlations between ETSA and biomass from laboratory experiments and field investigations allow ETSA (at constant temperature of the assay: $20^{\circ} \mathrm{C}$ ) to be used as an estimator for microbial biomass. However, the deciding importance of nutritional factors prevents the direct application of results obtained with cultured organisms to natural environments. A compromise conversion factor (biomass-carbon $=$ ETSA $\times$ 14.3, where carbon is in $\mu \mathrm{g}$ and ETSA in $\mu \mathrm{l} \mathrm{O} \mathrm{h}^{-1}$ ) is proposed.

(3) The actual rate of electron transfer $R$ (respiration) is difficult to assess from ETS activity since the latter is measured under $\mathrm{V}_{\max }$ conditions. R/ETSA ratios, sensitive to trophic conditions, decrease from coastal areas to deep sea zones but the gradient is not as steep as had been expected from the few data found in the literature. Although knowledge of R/ETSA ratios is important in ecological studies to understand the adaptative links between organisms and their habitat, its use to calculate sediment-community oxygen consumption is not easy and direct measures of respiration are preferable. 
To conclude, the assessment of ETSA to evaluate total microbenthic biomass is the main interest of this method, which should be reconsidered as a useful tool for oceanographic studies.

Acknowledgements. I am grateful to Dr T. Soltwedel (University of Hamburg) for his constructive remarks and comments on the first version of the manuscript. A part of this work has been carried out within the ECOMARGE program supported by CNRS-INSU

\section{LITERATURE CITED}

Anderson FO, Helder W (1987) Comparison of oxygen microgradients, oxygen flux rates and electron transport system activity in coastal marine sediments. Mar Ecol Prog Ser 37 $259-264$

Bämstedt U (1980) ETS activity as an estimator of respiratory rate of zooplankton populations. The significance of variations in environmental factors J Exp Mar Biol Ecol 42 : $267-283$

Berner RA (1980) Early diagenesis: a theoritical approach. Princeton University Press, Princeton, NJ

Bianchi A (1989) La microbiologie du domaine océanique profond. In: Bianchi M. Marty D, Bertrand JC, Caumette P, Gauthier $M$ (eds) Micro-organismes dans les écosystèmes aquatiques. Masson, Paris, p 283-304

Bligh EG, Dyer WJ (1959) A rapid method of total lipid extraction and purification. Can J Biochem Physiol 37:911-917

Bradford MM (1976) A rapid and sensitive method for the quantitation of microgram quantities of protein utilizing the principle of protein dye binding. Analyt Biochem 72 : $248-254$

Brugeaille M (1988) Qualification et quantification des biomasses dans la matière organique particulaire au sein de différents écosystèmes planctoniques et benthiques, par la mesure de l'activité des systèmes transporteurs d'électrons. Thèse de Doctorat, Université de Bordeaux

Cammen LM, Corwin S, Christensen JP (1990) Electron transport system (ETS) activity as a measure of benthic macrofaunal metabolism. Mar Ecol Prog Ser 65:171-182

Christensen JP (1981) Oxygen consumption, denitrification and sulfate reduction in coastal marine sediments. PhD dissertation, University of Washington, Seattle

Christensen JP (1983) Electron transport system activity and oxygen consumption in marine sediments. Deep Sea Res $30: 183-194$

Christensen JP, Owens TG, Devol AH, Packard TT (1980) Respiration and physiological state in marine bacteria. Mar Bıol 55:267-276

Christensen JP, Packard TT (1977) Sediment metabolism from the northwest African upwelling system. Deep Sea Res 24: $331-343$

Christensen JP, Packard TT (1979) Respiratory electron transport activities in phytoplankton and bacteria: comparison of methods. Limnol Oceanogr 24.576-583

de Wilde PAWJ, Berghuis EM, Kok A (1984) Structure and energy demand of the benthic community of the Oyster Ground, Central North Sea. Neth J Sea Res 18(1-2): 143-159

de Wilde PAWJ, Berghuis EM, Kok A (1986) Biomass and activity of benthic fauna on the Fladen Ground (Northern North Sea). Neth J Sea Res 20(2-3):313-323

de Wilde PAWJ, Kastoro WW, Berghuis EM, Aswandy I, Al Hakim I, Kok A (1989) Structure and energy demand of the benthic soft-bottom communifies of the Java Sea and around the Islands of Madura and Bali, Indonesia. Veth J Sea Res 23(4):449-461

de Wit R, Relexans JC, Bouvier T, Moriarty DJW (1996) Microbial respiration and diffusive oxygen uptake of deep-sea sediments in the Southern Ocean (ANTARES-I). Deep Sea Res II (in press)

Dubois M, Gilles KA, Hamilton JK, Rebers PA, Smith F (1956) Coloric method for determination of sugars and related substances. Analyt Chem 28:350-356

Elfaqir M (1993) Etude de la matière organique sur une marge continentale: quantité, qualité, bilan et réponses benthiques aux flux. Cas du Canyon du Cap-Ferret (Golfe de Gascogne). Thèse de Doctorat, Université de Bordeaux

Etien N'd (1985) Contribution à l'étude des effets d'un polluant métallique (le cadmium) sur la physiologie respiratoire des communautés micro et méiobenthiques de microcosmes sédimentaires expérimentaux. Thèse de Doctorat, Université de Bordeaux

Garabetian M (1992) Activité respiratoire dans la microcouche de surface et production de $\mathrm{CO}_{2}$ à l'interface airmer. Thèse de Doctorat, Université de Aix-Marseilles

Graf G, Bengtsson W (1984) Heat production, activity of the electron-transport-system (ETS), the ratio heat/ETS-activity, and ATP-turnover as useful tools in benthic ecological field studies. Arch Hydrobiol 19:249-256

Graf G, Schultz R. Peinert R, Meyer-Reil LA (1983) Benthic response to sedimentation events during autumn to spring at a shallow-water station in the western Kiel Bight. I. Analysis of processes on a community level. Mar Biol 77 : $235-246$

Hamilton RD, Holm-Hansen O (1967) Adenosine triphosphate content of marine bacteria. Limnol Oceanogr 12:319-324

Hobbie JE, Holm-Hansen O. Packard TT, Pomeroy LR, Sheldon RW. Thomas JP, Wiebe WJ (1972) A study of the distribution and activity of microorganisms in ocean waters. Limnol Oceanogr 17:544-555

Holm-Hansen $O$ (1969) Determination of microbial biomass in ocean profiles. Limnol Oceanogr 14:740-747

Houri-Davignon C (1990) Contribution à l'étude des relations entre les apports de matière organique particulaire à l'interface eau-sédiment et l'activité minéralisatrice du micro-méiobenthos. Thèse de Doctorat, Université de Bordeaux

Houri-Davignon C, Relexans JC, Etcheber H (1989) Measurement of actual electron transport system activity (ETS) in marine sediments by incubation with INT Environ Technol Lett 10:91-100

Jørgensen BB (1983) Processes at the sediment-water interface. In: Bolin B, Coox RB (eds) The major biochemical cycles and their interactions. Scope 21, J Wiley \& Sons, Chichester, p 477-509

Karl DM (1980) Cellular nucleotide measurements and applications in microbial ecology. Microbiol Rev 44:739-796

Kenner RA, Ahmed SI (1975) Measurements of electron transport activities in marine phytoplankton. Mar Biol 33: $119-127$

Mare MF (1942) A study of a marine benthic community with special reference to the microorganisms. J Mar Biol Ass UK 25:517-554

Meyer-Reil LA (1983) Benthic response to sedimentation events during autumn to spring at a shallow-water station in the western Kiel Bight. II. Analysis of bacterial populations. Mar Biol 77:247-256

Meyer-Reil LA, Bötler M, Dawson R, Liebezeit G, Swerinski $\mathrm{H}$, Wolter K (1980) Interrelationships between microbial and chemical parameters of sandy beach sediments, a 
summer aspect. Appl Environ Microbiol 39(4):787-802

Olanczuk-Neyman K, Vosjan JH (1977) Measuring respiratory electron transport system activity in marine sediment. Neth J Sea Res 11:1-13

Packard TT (1969) The estimation of oxygen utilization rate in seawater from the activity of the respiratory electron transport system in plankton. PhD thesis, University of Washington, Seattle

Packard TT (1971) The measurement of respiratory electron transport activity in marine phytoplankton. J Mar Res 29: $235-244$

Packard TT (1985a) Measurement of electron transport activity of microplankton. In: Jannasch H, Williams PJleB (eds) Advances in aquatic microbiology, Vol 3. Academic Press, London, p 207-261

Packard TT (1985b) Oxygen consumption in the ocean: measuring and mapping with enzyme analysis. In: Zirino $A$ (ed) Advances in chemistry series 209, Mapping strategies in chemical oceanography. American Chemical Society, Washington, DC, p 177-209

Packard TT. Devol A.H, King FD (1975) The effect of temperature on the respiratory electron transport system in marine plankton. Deep Sea Res 22:237-249

Packard TT, Garfield PC, Martinez R (1983) Respiration and the respiratory enzyme activity in aerobic and anaerobic cultures of the marine denitrifying bacterium, $P_{\text {seudo- }}$ monas perfectomarinus. Deep Sea Res 30(3A):227-243

Packard TT, Healy ML, Richards FA (1971) Vertical distribution of the activity of the respiratory electron transport system in marine plankton. Limnol Oceanogr 16:60-70

Pamatmat MM, Graf G, Bengtsson W, Novak CS (1981) Heat production, ATP concentration and electron transport activity of marine sediments. Mar Ecol Prog Ser 4:135-143

Pfannkuche O, Theeg $R$, Thiel $H$ (1983) Benthos activity, abundance and biomass under an area of low upwelling off Morocco, Northwest Africa. 'Meteor' Forsch-Ergebn 36: $85-96$

Relexans JC (1989) Effets des polluants sur la physiologie respiratoire de la méiofaune. Contrat no. 87270 , Ministère de l'Equipement et du Logement, de l'Aménagement du Territoire et des Transports-Environnement, Paris

Relexans JC (1996) Measurement of the respiratory electron transport system (ETS) activity in marine sediments: Stateof-the-art and interpretation. 1. Methodology and review of literature data. Mar Ecol Prog Ser 136:277-287

Relexans JC, Deming J, Dinet A, Gaillard JF, Sibuet M (1996) Sedimentary organic matter and micro-meiobenthos with relation to trophic conditions in the Northeast tropical Atlantic. Deep Sea Res (in press)

Relexans JC, Etcheber H, Beliard M (1993a) Relationships between the quality of the organic matter and the benthic respiratory potential in surficial sediments of the Bay of Biscay (France). In: Sorbe JC, Jouanneau JM (eds) Third
International Workshop on the Bay of Biscay. CNRS publisher, Arcachon, France, p 163-167

Relexans JC, Etcheber $H$, Castel J, Escaravage V, Auby I (1992) Benthic respiratory potential with relation to sedimentary carbon quality in seagrass beds and oyster parks in the tidal flats of Arcachon Bay, France. Estuar Coast Shelf Sci 34:157-170

Relexans JC, Gaucher B, Etcheber H (1984) Activité des systèmes transporteurs d'électrons (ETS) et paramètres biochimiques de quelques algues et bactéries planctoniques d'eaux douces cultivées in vitro. CR Acad Sci, Paris 299:943-946

Relexans JC, Lin RG, Castel J, Etcheber H, Laborde P (1993b) Response of biota to sedimentary organic matter quality of the West Gironde mud patch, Bay of Biscay (France). Oceanol Acta 15\{6\}:639-649

Romano JC, Laborde P, Mimura T, de Souza-Lima Y (1987a) Approche discriminante de contributions de différents échelons micro-planctoniques aux mesures globales d'ETS dans des échantillons de mer. b. Bacteria. Int Rev Ges Hydrobiol 72:607-630

Romano JC, Mimura T, de Souza-Lima Y (1987b) Approche discriminante de contributions de différents échelons micro-planctoniques aux mesures globales d'ETS dans des échantillons de mer a. Phytoplancton. Int Rev Ges Hydrobiol 72:457-472

Rowe G, Sibuet M, Deming J, Khripounoff A, Tietjen J, Macko S, Theroux R (1991) 'Total' sediment biomass and preliminary estimates of organic carbon residence time in deep sea benthos. Mar Ecol Prog Ser 79:99-114

Sorokin Yul (1978) Decomposition of organic matter and nutrient regeneration. In: Kinne $O$ (ed) Marine ecology, Vol 4. John Wiley \& Sons, New York, p 501-616

Sorokin Yul (1981) Microheterotrophic organisms in marine ecosystems. In: Longhurst AR (ed) Analysis of marine ecosystems. Academic Press, London, p 293-341

Van Es FB, Meyer-Reil LA (1982) Biomass and metabolic activity of heterotrophic marine bacteria. In: Marschall KC (ed) Advances in microbial ecology, Vol 6. Plenum Publishing Corporation, New York, p 111-170

Vosjan JH, Niewland G (1987) Microbial biomass and respiratory activity in the surface waters of the east Banda Sea and northwest Arafura Sea (Indonesia) at the time of the southeast monsoon. Limnol Oceanogr 32:767-775

Vosjan JH, Olanczuk-Neyman KM (1977) Vertical distribution of mineralization processes in a tidal sediment. Neth $\mathrm{J}$ Sea Res 11:14-23

Wieser W, Zech M (1976) Dehydrogenases as tools in the study of marine sediments. Mar Biol 36:113-122

Williams PJleB (1.984) A review of measurements of respiration rates of marine plankton populations. In: Hobbie JE, Williams PJleB (eds) Heterotrophic activity in the sea. Plenum Press, New York, p 357-389

Manuscript first received: July 3, 1995

Revised version accepted: December 18, 1995 